\title{
Pengalaman Terjadinya Bullying yang Berdampak Pada Kesehatan Mental
}

\author{
Widya Rahmawati, Muhammad Ali Sodik \\ Institut Ilmu Kesehatan STRADA INDONESIA \\ rahmawatiwidya82@gmail.com, alisodik2012@gmail.com
}

\begin{abstract}
Abstrak
Bullying adalah pola perilaku, bukan insiden yang terjadi sekali-kali. Anak-anak yang melakukan bullying biasanya berasal dari status sosial atau posisi kekuasaan yang lebih tinggi, seperti anakanak yang lebih besar, lebih kuat, atau dianggap populer sehingga dapat menyalahgunakan posisinya. Anakanak yang paling rentan menghadapi risiko lebih tinggi untuk di-bully seringkali adalah anak-anak yang berasal dari masyarakat yang terpinggirkan, anak-anak dari keluarga berpenghasilan rendah, anak-anak dengan penampilan atau ukuran tubuh yang berbeda, anak-anak penyandang disabilitas, atau anak-anak migran dan pengungsi. Bullying dapat menimbulkan dampak yang berbahaya dan jangka panjang bagi anakanak. Selain efek fisik dari bullying, anak-anak dapat mengalami masalah kesehatan mental dan emosional, termasuk depresi dan kecemasan, yang dapat menyebabkan penyalahgunaan narkoba dan penurunan prestasi di sekolah. Jika hal-hal ini terus dibiarkan dalam tatanan kehidupan mereka maka akan mengakibatkan pelaku tumbuh menjadi pelaku kriminal atau sosok penguasa yang tak punya empati terhadap orang lain. Pelaku bullying akan menganggap bahwa cara penyelesaian masalah yang paling baik adalah dengan cara-cara kekerasan atau pelaku beranggapan dengan mengintimidasi orang lain maka akan memenuhi keinginannya. Hal ini akan mendorong sifat premanisme yang akan terbawa hingga dewasa dan mengakibatkan ketidaknyamanan di masyarakat. Untuk itu pola asuh anak juga sangat mempengaruhi kepribadian anak. Pola asuh ini akan menentukan bagaimana anak berinteraksi dengan orangtuanya.
\end{abstract}

Kata kunci : bullying, anak, kesehatan mental, intimidasi.

\section{Latar Belakang}

Bullying di kalangan remaja masih sering kita jumpai. Masyarakat menganggap hal ini sudah biasa karena masa remaja adalah masa dimana remaja mencari jati dirinya dan kenakalannya akan hilang sendiri. Apabila dibiarkan, maka akan timbul masalah karena dampaknya berpengaruh pada perkembangan jiwa. Pelaku bullying bisa berpotensi menjadi pribadi yang sewenangwenang. Jika hal-hal ini terus dibiarkan dalam tatanan kehidupan mereka maka akan mengakibatkan pelaku tumbuh menjadi pelaku kriminal atau sosok penguasa yang tak punya empati terhadap orang lain. Pelaku bullying akan menganggap bahwa cara penyelesaian masalah yang paling baik adalah dengan cara-cara kekerasan atau pelaku beranggapan dengan mengintimidasi orang lain maka akan memenuhi keinginannya. Hal ini akan mendorong sifat premanisme yang akan terbawa hingga dewasa dan mengakibatkan ketidaknyamanan di masyarakat. Perilaku kasar maupun tindakan bullying dapat terjadi karena tidak adanya cinta dan kehangatan dalam keluarga. Akhir-akhir ini kekerasan memang telah menjadi bagian dari kehidupan remaja. Kekerasan antar sebaya atau bullying merupakan suatu tindak kekerasan fisik dan psikologis yang dilakukan seseorang atau kelompok. Tindakan tersebut dimaksudkan untuk melukai, membuat takut atau membuat tertekan seseorang (anak atau siswa) lain yang dianggap lemah, misalnya secara fisik lebih lemah, minder dan kurang mempunyai teman, sehingga tidak mampu mempertahankan diri. Hal ini terjadi karena masih banyak orang tua yang melakukan corporal punishment dan menganggap wajar hal tersebut dengan alasan untuk mendisplinkan. Sehingga kurang disadari orang tua yang dilakukan sebenarnya adalah bentuk lain dari 
kekerasan. Misalnya ketika anak melakukan kesalahan, orang tua sering kali membentak anak dan mengatakan kata-kata kasar serta memukul anak, menerapkan disiplin dan sistem hukuman yang berlebihan, yang tidak berusaha berkomunikasi, serta secara keterlaluan memarahi anak- anaknya, sehingga anak menganggap cara tersebut adalah benar sehingga anak mengaplikasikannya dalam pergaulan.

Rahman (2004) menyebutkan bentuk aktualisasi sumber oleh seseorang terhadap keluarga terwujud dalam bentuk upaya orang tua mendidik putra-putrinya dengan sebaik-baiknya. Sebagaimana dikutip anak pembohong umumnya berasal dari keluarga yang sering berbohong. Sebab, sebagian besar perilaku anak dipengaruhi oleh pengalamannya dirumah. Bila sebuah keluarga hidup damai dan tenang, maka diluar rumah, seluruh keluarga tersebut akan terbentuk oleh kebiasaaanya hidup damai dan tenang. Sebaliknya, keluarga yang broken home dan penuh dengan konflik akan mempengaruhi pola interaksinya di luar rumah.

Bullying adalah suatu bentuk agresi dimana terdapat kekuatan yang tidak seimbang antara pelaku dan korban. Pelaku selalu mempunyai kekuatan yang lebih dari pada korbannya. Bullying dapat berupa tindakan fisik, verbal dan psikologis. Bullying dapat terjadi secara langsung (tatap muka) atau tidak langsung (bersembunyi dibalik orang lain). Contoh tindakan bullying secara langsung adalah memukul dan memaki orang. Sedangkan contoh tindakan bullying secara tidak langsung adalah pengucilan dan gossip (Papler \& Craig.2000).

Jika selama ini kita hanya tahu banyak terjadinya kasus bullying pada remaja, bukan tidak mungkin semua itu berawal dari masa kanak-kanak. Salah satu hal yang perlu diteliti lebih lanjut juga adalah latar belakang keluarga. Penting untuk dilihat darimana anak-anak tersebut belajar bullying tersebut. Harus dilihat apakah keluarga mereka harmonis, atau sering bertengkar, kemudian juga penting untuk dilihat anak tersebut merupakan anak ke berapa dari berapa bersaudara, bagaimana interaksi anak-anak tersebut dengan kakak atau adiknya dan sifat anak itu sendiri. Terjadinya kekerasan antar sebaya semakin menguat mengingat adanya faktor pubertas dan krisis identitas, yang normal terjadi pada perkembangan remaja. Dalam rangka mencari identitas dan ingin eksis, biasanya remaja lalu gemar membentuk geng. Geng remaja sebenarnya sangat normal dan bisa berdampak positif, namun jika orientasi geng kemudian 'menyimpang' hal ini kemudian menimbulkan banyak masalah. Dari relasi antar sebaya juga ditemukan bahwa beberapa remaja menjadi pelaku bullying karena 'balas dendam' atas perlakuan penolakan dan kekerasan yang pernah dialami sebelumnya (misalnya pada saat masih SD atau anak-anak). Berbicara mengenai kekerasan anak, ditemukan bahwa anak bisa menjadi subjek/pelaku maupun objek kekerasan. Anak sebagai pelaku kekerasan/subjek, biasanya disebabkan ia memiliki pengalaman sebagai objek kekerasan itu sendiri. Anak berperilaku seperti itu sebagai bagian dari imitasi atupun pengekspresian pengalaman-pengalaman mereka, entah itu disadari ataupun tidak. Kekerasan pada anak tergantung pada pola asuh dan pola perlakuan orang tua terhadap anak. Pola asuh anak juga sangat mempengaruhi kepribadian anak. Pola asuh ini menentukan bagaimana anak berinteraksi dengan orangtuanya.

Hurlock (1998 : 30), membagi pola asuh menjadi tiga: yaitu pola asuh otoriter, pola asuh demokrasi, dan pola asuh permisif. Perlakuan orang tua ataupun pengasuh kepada anak sangat mempengaruhi kepribadian anak. Masa kanakkanak adalah masa dimana anak menunjukkan ekspresi dan eksistensinya sebagai seorang manusia yang utuh. Kegagalan dalam masa ini, menurut Freud (Sumadi,2011), akan terpendam dan menjadi pengalaman bawah sadar anak, yang menjadikan pengalaman anak sebagai referensi dalam menjadi hidupnya.

\section{Kasus / Masalah}

Lapangan di kawasan Bintaro menjadi saksi bisu aksi kekerasan yang terjadi di SMA 90 Jakarta. Siswa kelas 1 dipaksa buka baju, push up, lari dan ditampar."Dibawa kakak kelas dari parkiran ke daerah Bintaro (belakang McD). Di sana disuruh push up, buka baju dan lari. Di sana juga disuruh suit. Yang kalah, ditampar dengan keras. Kirakira dari zuhur sampai ashar," kata Aba. Hal ini disampaikan Aba di SMA 90 Jakarta, Jl Sabar, 
Petukangan Selatan, Pesanggrahan, Jakarta Selatan, Senin (1/12/2008). Aba mengalami luka bibir pecah, memar di pelipis. Dikatakan dia, sedikitnya 68 siswa kelas 1 dari 9 kelas dipaksa ikut 'penataran.' "Disuruh kelas 2 dan 3, katanya untuk penataran," ujarnya. Menurut Aba, ada juga teman-temannya yang dibawa ke lantai 3 sekolah. "Tetapi nggak tahu diapain. Biasanya jam-jam istirahat. Dengar dari anak-anak cuma dikasih tahu, anak kelas 1 parkir di belakang," tutur Aba. SMA 90 lantas menskorsing 31 siswanya yang terlibat bullying selama 5 hari. Para senior menandatangani surat perjanjian di atas materai agar tidak mengulangi perbuatannya.

\section{Tinjauan Pustaka}

Bullying merupakan aktivitas sadar yang tujuannya untuk melukai dan menyakiti seseorang dan dilakukan secara berulang-ulang. Olweus (1997) mengatakan bahwa bullying adalah perilaku negatif yang mengakibatkan seseorang dalam keadaan tidak nyaman/terluka dan biasanya terjadi berulangulang yang ditandai dengan adanya ketidakseimbangan kekuasaan antara pelaku dan korban. Perilaku bullying ini tidak lepas dari yang namanya keinginan untuk berkuasa dan juga menjadi seseorang yang ditakuti di lingkungan sekolahnya. Menurut Siswati dan Widayanti (2009) perilaku bullying merupakan salah satu bentuk dari perilaku agresi. Seperti ejekan, hinaan, dan ancaman seringkali merupakan sebagai suatu pancingan yang dapat mengarah ke agresi. Menurut Coloroso (Siswati \& Widayanti, 2009) bullying akan selalu melibatkan adanya ketidakseimbangan kekuatan, niat untuk mencederai, ancaman agresi lebih lanjut, dan teror. Menurut Smith dan Thompson (Yusuf \& Fahrudin, 2012) bully diartikan sebagai seperangkat tingkah laku yang dilakukan secara sengaja dan menyebabkan kecederaan fisik serta psikologikal yang menerimanya. Sehingga dapat diartikan bahwa pelaku bullying ini menyerang korban secara sadar dan sengaja tanpa memikirkan kondisi korban.

Berdasarkan pengertian di atas, bullying dapat diartikan sebagai salah satu bentuk perilaku agresivitas yang dilakukan secara berulang-ulang dengan tujuan untuk melukai dan menindas seseorang yang di anggapnya lebih rendah dan lebih lemah dari diri pelaku bullying guna untuk memperoleh kekuasaan dan ditakuti.

-Aspek-aspek Bullying Berdasarkan data-data yang diperoleh di atas, terdapat aspek-aspek yang menunjukkan adanya perilaku bullying. Solberg \& Olweus (Magfirah \& Rachmawati, 2009) mengemukakan beberapa aspek mengenai perilaku bullying meliputi:

-Aspek verbal kegiatan yang bertujuan untuk menyakiti seseorang dengan cara menertawakan dengan menjadikannya bahan lelucon, menyapa seseorang dengan nama julukan sehingga akan membuat seseorang manjadi tidak nyaman, sakit hati dan marah.

-Aspek indirect yaitu kegiatan yang bertujuan untuk menolak atau mengeluarkan dan menjauhi seseorang dari kelompok pertemanan atau meninggalkannya dari berbagai hal secara disengaja seperti memfitnah seseorang dengan menceritakan kebohongan tentang seseorang agar orang tersebut di nilai buruk oleh temantemannya.

-Aspek physical yaitu kegiatan melukai seseorang dengan cara Memukul, menendang, mendorong, mempermainkan atau meneror dan melakukan hal-hal yang bertujuan untuk menyakiti dan mencederai. Menurut Riauskina, dkk (Argiati, 2010) mengelompokkan perilaku bullying ke dalam 5 (lima) bentuk. Lima bentuk perilaku bullying tersebut yaitu :

a. Kontak Fisik Langsung Bentuk kontak langsung antara lain seperti memukul, mendorong, menggigit, menjambak, menendang, mengunci seseorang dalam ruangan, mencubit, mencakar, memeras, dan merusak barang-barang yang dimiliki orang lain.

b. Kontak Verbal Langsung Kontak verbal langsung yang ditunjukkan antara lain seperti mengancam, mempermalukan, merendahkan, menganggu, memberi panggilan nama, mencela atau mengejek, mengintimidasi, memaki, dan menyebarkan gosip.

c. Perilaku Non-Verbal Langsung Perilaku nonverbal langsung yang ditunjukkan antara lain seperti melihat dengan sinis, menjulurkan lidah, menampilkan ekspresi muka yang merendahkan, 
mengejek atau mengancam (biasanya disertai dengan bullying fisik atau verbal).

d. Perilaku Non Verbal tidak langsung 12 Perilaku non-verbal tidak langsung yang ditunjukkan antara lain seperti mendiamkan seseorang, memanipulasi persahabatan sehingga menjadi retak, sengaja mengucilkan atau mengabaikan, dan mengirimkan surat kaleng.

e. Pelecehan Seksual Bentuk perilaku bullying dengan pelecehan seksual dikategorikan kedalam bentuk perilaku agresi fisik atau verbal.

Berdasarkan penjelasan mengenai aspek-aspek perilaku bullying diatas dapat disimpulkan bahwa ciri-ciri yang menunjukkan perilaku bullying dapat dilakukan secara Verbal, Indirect, dan secara physical dalam bentuk langsung maupun tidak langsung.

Faktor yang mempengaruhi perilaku bullying. Faktor-faktor yang mempengaruhi bullying menurut Yusuf \& Fahrudin (2012) yaitu :

- Faktor individu Terdapat dua kelompok individu yang terlibat secara langsung dalam peristiwa buli, yaitu pembuli dan korban buli. Kedua kelompok ini merupakan faktor utama yang mempengaruhi perilaku buli.

Ciri kepribadian dan sikap seseorang individu mungkin menjadi penyebab kepada suatu perilaku buli.

a. Pembully. Pembuli cenderung menganggap dirinya senantiasa diancam dan berada dalam bahaya. Pembuli ini biasanya bertindak menyerang sebelum diserang. Biasanya, pembuli memiliki kekuatan secara fisik dengan penghargaan diri yang baik dan berkembang. Pembuli juga biasanya terdiri dari kelompok yang coba membina atau menunjukkan kekuasaan kelompok mereka dengan mengganggu dan mengancam anakanak atau murid lain yang bukan anggota kelompok. Kebanyakan dari mereka menjadi pembuli sebagai bentuk balas dendam. Dalam kasus ini peranan sebagai korban buli telah berubah peranan menjadi pembuli.

b. Korban bully. Korban buli ialah seseorang yang menjadi sasaran bagi berbagai tingkah laku agresif. Dengan kata lain, korban buli ialah orang yang dibuli atau sasaran pembuli. Anak-anak yang sering menjadi korban buli biasanya menonjolkan ciri-ciri tingkah laku internal seperti bersikap pasif, sensitif, pendiam, lemah dan tidak akan membalas sekiranya diserang atau diganggu. Secara umum, anak-anak yang menjadi korban buli karena mereka memiliki kepercayaan diri dan penghargaan diri (self esteem) yang rendah.

- Faktor keluarga. Latar belakang keluarga turut memainkan peranan yang penting dalam membentuk perilaku bullying. Orang tua yang sering bertengkar atau berkelahi cenderung membentuk anak-anak yang beresiko untuk menjadi lebih agresif. Anakanak yang mendapat kasih sayang yang kurang, didikan yang tidak sempurna dan kurangnya diberikan ajaran yang positif akan berpotensi untuk menjadi pembuli.

- Faktor teman sebaya Teman sebaya memainkan peranan yang tidak kurang pentingnya terhadap perkembangan dan pengukuhan tingkah laku buli, sikap anti sosial dan tingkah laku di kalangan anakanak. Kehadiran teman sebaya sebagai pengamat, secara tidak langsung, membantu pembuli memperoleh dukungan kuasa, popularitas, dan status. Dalam banyak kasus, saksi atau teman sebaya yang melihat, umumnya mengambil sikap berdiam diri dan tidak mau campur tangan.

- Faktor sekolah Lingkungan, praktik dan kebijakan sekolah mempengaruhi aktivitas, tingkah laku, serta interaksi pelajar di sekolah. Rasa aman dan dihargai merupakan dasar kepada pencapaian akademik yang tinggi di sekolah. Jika hal ini tidak dipenuhi, maka pelajar mungkin bertindak untuk mengontrol lingkungan mereka dengan melakukan tingkah laku anti sosial seperti melakukan buli terhadap orang lain. Managemen dan pengawasan disiplin sekolah yang lemah akan mengakibatkan lahirnya tingkah laku buli di sekolah

- Faktor media. Paparan aksi dan tingkah laku kekerasan yang sering ditayangkan oleh 
televisi dan media elektronik akan mempengaruhi tingkah laku kekerasan anakanak dan remaja. Beberapa waktu yang lalu, masyarakat diramaikan oleh perdebatan mengenai dampak tayangan Smack-Down di sebuah televisi swasta yang dikatakan telah mempengaruhi perilaku ke-kerasan pada anak-anak.

- Faktor kontrol diri. Kontrol diri adalah faktor yang berasal dari diri individu. Kontrol diri yang dimiliki setiap individu berbeda-beda, ada yang memiliki kontrol diri yang tinggi dan ada yang memiliki kontrol diri yang rendah.

Sedangkan faktor yang mempengaruhi perilaku bullying menurut astuti (2008) antara lain:

1. Perbedaan kelas (senioritas), ekonomi, agama, jender, etnisitas atau rasisme. Biasanya muncul karena ada perbedaan strata atau tingkat ekonomi dari mayoritas yang berada di lingkungan tersebut yang menyebabkan munculnya perilaku bullying.

2. Tradisi senioritas, sebagai tempat munculnya perilaku bullying, yang paling terlihat saat MOS atau masa orientasi siswa dimana kakak-kakak kelasnya selalu menunjukkan bahwa mereka lah yang paling berkuasa karena mereka 16 sudah lama bersekolah di sekolah tersebut daripada adik tingkatnya tersebut, sehingga adik tingkatnya harus menuruti apa kata kakak kelasnya.

3. Senioritas, sebagai salah satu perilaku bullying seringkali pula justru diperluas oleh siswa sendiri sebagai kejadian yang bersifat laten. Bagi mereka keinginan untuk melanjutkan masalah senioritas ada untuk hiburan, penyaluran dendam, iri hati atau mencari popularitas, melanjutkan tradisi atau menunjukkan kekuasaan.

4. Keluarga yang tidak rukun, juga menjadi salah satu timbulnya perilaku bullying, jika para orang tua sering bertengkar bahkan sampai menunjukkan kekerasan di hadapan anak-anaknya maka anak akan mengikuti apa yang dilakukan oleh orang tuanya, begitu juga jika kurangnya rasa kasih sayang yang diberikan orang tua kepada anaknya, hal ini juga akan membuat anak memiliki perilaku agresif.

5. Situasi sekolah yang tidak harmonis, hal ini juga memberikan pengaruh munculnya perilaku bullying, seperti halnya jika para guru yang kurang dalam memberikan pengawasan terhadap para siswa, dan adanya peraturan yang dibuat hanya untuk formalitas saja tetapi tidak benar-benar dipergunakan semestinya.

6. Karakter individu atau kelompok seperti : a. Dendam atau iri hati.

b. Adanya semangat ingin menguasai korban dengan kekuasaan fisik dan daya tarik seksual.

c. Untuk meningkatkan popularitas pelaku di kalangan teman sepermainannya (peers).

d. Persepsi nilai yang salah atas perilaku korban, karena rendahnya kepercayaan diri dan (self esteem) yang dimiliki korban, korban seringkali merasa bahwa dirinya memang pantas untuk dibully.

\section{Pembahasan}

\section{A. Pengertian Bullying}

Bullying adalah pola perilaku, bukan insiden yang terjadi sekali-kali. Anak-anak yang melakukan bullying biasanya berasal dari status sosial atau posisi kekuasaan yang lebih tinggi, seperti anak-anak yang lebih besar, lebih kuat, atau dianggap populer sehingga dapat menyalahgunakan posisinya. Anak-anak yang paling rentan menghadapi risiko lebih tinggi untuk di-bully seringkali adalah anak-anak yang berasal dari masyarakat yang terpinggirkan, anakanak dari keluarga berpenghasilan rendah, anakanak dengan penampilan atau ukuran tubuh yang berbeda, anak-anak penyandang disabilitas, atau anak-anak migran dan pengungsi.

\section{B. Dampak Bullying}

Dampak Dampak bullying dapat mengancam setiap pihak yang terlibat, baik anak- anak yang di-bully, anak-anak yang mem-bully, anak-anak yang menyaksikan bullying, bahkan sekolah dengan isu bullying secara keseluruhan. Bullying dapat membawa pengaruh buruk terhadap kesehatan fisik maupun mental anak. Pada kasus yang berat, bullying dapat menjadi pemicu 
tindakan yang fatal, seperti bunuh diri dan sebagainya.

Dampak dari bullying adalah:

a. Dampak bagi korban.

- Depresi dan marah

- Rendahnya tingkat kehadiran dan rendahnya prestasi akademik siswa

- Menurunnya skor tes kecerdasan (IQ) dan kemampuan analisis siswa.

b. Dampak bagi pelaku.

Pelaku memiliki rasa percaya diri yang tinggi dengan harga diri yang tinggi pula, cenderung bersifat agresif dengan perilaku yang pro terhadap kekerasan, tipikal orang berwatak keras, mudah marah dan impulsif, toleransi yang rendah terhadap frustasi. Memiliki kebutuhan kuat untuk mendominasi orang lain dan kurang berempati terhadap targetnya.

Dengan melakukan bullying, pelaku akan beranggapan bahwa mereka memiliki kekuasaan terhadap keadaan. Jika dibiarkan terus menerus tanpa intervensi, perilaku bullying ini dapat menyebabkan terbentuknya perilaku lain berupa kekerasan terhadap anak dan perilaku kriminal lainnya.

c. Dampak bagi siswa lain yang menyaksikan bullying. Jika bullying dibiarkan tanpa tindak lanjut, maka para siswa lain yang menjadi penonton dapat berasumsi bahwa bullying adalah perilaku yang diterima secara sosial. Dalam kondisi ini, beberapa siswa mungkin akan bergabung dengan penindas karena takut menjadi sasaran berikutnya dan beberapa lainnya mungkin hanya akan diam saja tanpa melakukan apapun dan yang paling parah mereka merasa tidak perlu menghentikannya.

\section{Pencegahan Bullying}

Pencegahan Dilakukan secara menyeluruh dan terpadu, dimulai dari anak, keluarga, sekolah dan masyarakat.

1) Pencegahan melalui anak dengan melakukan pemberdayaan pada anak agar : a. Anak mampu mendeteksi secara dini kemungkinan terjadinya bullying

b. Anak mampu melawan ketika terjadi bullying pada dirinya

c. Anak mampu memberikan bantuan ketika melihat bullying terjadi (melerai/mendamaikan, mendukung teman dengan mengembalikan kepercayaan, melaporkan kepada pihak sekolah, orang tua, tokoh masyarakat)

2) Pencegahan melalui keluarga, dengan meningkatkan ketahanan keluarga dan memperkuat pola pengasuhan. Antara lain :

a. Menanamkan nilai-nilai keagamaan dan mengajarkan cinta kasih antar sesama

b. Memberikan lingkungan yang penuh kasih sayang sejak dini dengan memperlihatkan cara beinterakasi antar anggota keluarga.

c. Membangun rasa percaya diri anak, memupuk keberanian dan ketegasan anak serta mengembangkan kemampuan anak untuk bersosialiasi

d. Mengajarkan etika terhadap sesama (menumbuhkan kepedulian dan sikap menghargai), berikan teguran mendidik jika anak melakukan kesalahan

e. Mendampingi anak dalam menyerap informasi utamanya dari media televisi, internet dan media elektronik lainnya.

3) Pencegahan melalui sekolah

a. Merancang dan membuat desain program pencegahan yang berisikan pesan kepada murid bahwa perilaku bully tidak diterima di sekolah dan membuat kebijakan "anti bullying".

b. Membangun komunikasi efektif antara guru dan murid

c. Diskusi dan ceramah mengenai perilaku bully di sekolah

d. Menciptakan suasana lingkungan sekolah yang aman, nyaman dan kondusif.

e. Menyediakan bantuan kepada murid yang menjadi korban bully. 
f. Melakukan pertemuan berkala dengan orangtua atau komite sekolah

4) Pencegahan melalui masyarakat dengan membangun kelompok masyarakat yang peduli terhadap perlindungan anak dimulai dari tingkat desa/kampung (Perlindungan Anak Terintegrasi Berbasis MAsyarakat: PATBM).

\section{Kesimpulan}

Secara keseluruhan tindakan bullying atau intimidasi bukan tindakan terpuji yang harus dilakukan. Melakukan tindakan bullying terhadap orang - orang tertentu juga akan berdampak pada kesehatan mental korban yang bisa mengakibatkan gangguan depresi, kecemasan serta melakukan tindakan bunuh diri. Untuk itu perlu adanya bimbingan dan pencegahan bullying baik dilingkungan sekolah, keluarga, maupun masyarakat.

\section{Daftar Pustaka}

https://www.unicef.org/indonesia/id/caramembicarakan-bullying-dengan-anak-anda .25 Januari 2021(14.30)

http://eprints.umm.ac.id/30048/1/iiptummppgdl-indahpurna-28668-2-babi.pdf . 25 Januari 2021(14.45)

oleh Al Wicaksana. 2017 https://dspace.uii.ac.id/bitstream/handle/1234 56789/10434/05.2\%20bab\%202.pdf?sequence= 6\&isAllowed $=y$. 25 Januari 2021(16.00)

https://www.kemenpppa.go.id/lib/uploads/list/ 8e022-januari-ratas-bullying-kpp-pa.pdf .25 Januari 2021(16.30)

https://news.detik.com/berita/d-1979089/5kasus-bullying-sma-di-jakarta . 25 Januari 2021(18.00)

Awan, I., \& Sodik, M. A. (2018). Diskriminasi dan Kesehatan Mental. 